\title{
RAGAM DAN ARAH PERTANYAAN PENYIDIK DALAM BERITA ACARA PEMERIKSAAN PERKARA PIDANA ANAK
}

\author{
Andika Dutha Bachari, Dadang Sudana, Wawan Gunawan \\ Universitas Pendidikan Indonesia \\ andika@upi.edu
}

\begin{abstract}
Abstrak
Penelitian ini bertujuan untuk melaporkan sebuah studi mengenai pola-pola strategi aparat penyidik kepolisian Indonesia dalam memeriksa kasus pidana yang melibatkan anak-anak. Kemampuan untuk mengajukan pertanyaan sangat penting bagi para penyidik. Ragam, substansi, dan arah pertanyaan para penyidik sangat menentukan nilai informasi yang diperoleh melalui pemeriksaan. Dengan menggunakan paradigma kualitatif Strauss dan Corbin, ground theory Glacer dan kerangka analisis Milne, penelitian ini mengungkapkan bahwa terlepas masih adanya pertanyaan tak produktif yang menghasilkan informasi tak bernilai bukti dalam berita acara pemeriksaan tersangka, para penyidik telah memberi kompensasi dengan menerapkan strategi bertanya untuk mengungkap lebih banyak informasi bernilai bukti. Oleh karena itu, efektivitas pertanyaan lebih ditentukan oleh strategi bertanya yang ditindaklanjuti penyidik daripada strategi bertanya yang sebelumnya ditujukan kepada para tersangka.
\end{abstract}

Kata Kunci: pertanyaan, penyidik, BAP, pidana, anak

\begin{abstract}
This study aims to report a study on the patterns of Indonesian police strategies in examining criminal cases involving children. The ability to ask questions is instrumental for the investigators. The variety, content, and direction of the investigators' questions determine the value of information obtained from investigations. By using Strauss and Corbin's qualitative paradigm, Glacer's ground theory as well as Milne's analytical frameworks, the present study has revealed that despite the fact that police investigation reports contained a lot of unproductive questions that might lead to unproductive answers, they compensated these with other investigative questioning strategies to reveal more information. Therefore effectiveness of questioning is more determined by these follow-up strategies than by the initial questions addressed to the suspects.
\end{abstract}

Keywords: questions, investigators, BAP, criminal, child

\section{PENDAHULUAN}

Proses mengajukan pertanyaan untuk memperoleh keterangan dari terperiksa yang dilakukan penyidik disebut pemeriksaan. Dalam proses penyidikan, pemeriksaan memegang peran penting sebagai suatu upaya yang menentukan keberhasilan penanganan perkara pidana (Harahap, 2010:295). Tujuan utama pemeriksaan di dalam proses penyidikan perkara pidana adalah untuk mengumpulkan keterangan atau informasi dari terperiksa sehingga dengan keterangan tersebut suatu perkara pidana dapat menjadi jelas dan diketahui secara pasti siapa pelaku tindak pidana tersebut (Kitab Undang-Undang Hukum Acara Pidana [KUHAP], Pasal 1, nomor 2). Dalam 
rangka mencari dan mengumpulkan keterangan dari terperiksa, penyidik melakukan pemeriksaan dengan cara mengajukan pertanyaan kepada terperiksa.

Informasi atau keterangan yang dibutuhkan dari terperiksa dalam pemeriksaan perkara pidana tentu saja berbeda-beda. Namun, jika dikaitkan dengan fungsi produk fisik hasil pemeriksaan, yaitu berita acara pemeriksaan (BAP), maka keterangan yang diperlukan penyidik di dalam proses pemeriksaan adalah informasi penting yang dapat menerangkan kejadian perkara pidana itu dengan sejelas-jelasnya atau bernilai bukti (Gregory, 2011:203). Pemeriksaan yang dilakukan penyidik diarahkan untuk mengumpulkan keterangan faktual terkait hal-hal yang didengar, dilihat, dirasakan, dan dialami oleh terperiksa tentang suatu perkara pidana. Dalam hal ini, terperiksa yang menjalani pemeriksaan dituntut untuk menyampaikan keterangan yang didasarkan pada suatu latar belakang pengetahuan sehingga keterangan yang disampaikan dapat dipahami sebagai informasi yang logis. Latar belakang pengetahuan yang dijadikan dasar oleh terperiksa dibagikan kepada penyidik dalam proses pemeriksaan, sehingga penyidik dan terperiksa dapat berkomunikasi secara efektif. Dalam KUHAP, Pasal 75 ayat (2) dan Surat Keputusan Kapolri Nomor 1205/IX/2000, Bab III, angka 8.3.a-8.3.d tentang Petunjuk Pelaksanaan dan Petunjuk Teknis Penyidikan Pidana, pemeriksaan penyidik kepada terperiksa dapat dilakukan melalui tiga cara seperti berikut.

1. Dengan cara meminta saksi untuk menceritakan segala hal yang diketahui, dilihat, didengar, dan dialami tentang peristiwa pidana yang tengah diselidiki melalui penyidikan. Hal-hal yang disampaikan oleh terperiksa itu kemudian dicatat penyidik ke dalam BAP.

2. Dengan cara mengajukan pertanyaan-pertanyaan kepada terperiksa terkait pengetahuannya terhadap peristiwa pidana yang sedang diselidiki melalui pemeriksaan. Pertanyaan dan jawaban tersebut kemudian dicatat oleh penyidik ke dalam BAP.

3. Dengan cara menggabungkan kedua cara seperti yang telah disebutkan pada angka 1 dan 2 , yaitu: (1) dengan memberikan kesempatan kepada terperiksa untuk menceritakan segala hal yang diketahui, dilihat, dialami, dan didengar oleh terperiksa, dan (2) dengan mengajukan pertanyaan-pertanyaan kepada terperiksa untuk menggali keterangan tentang pengetahuan terperiksa terhadap perkara pidana yang terjadi. Kedua hal yang dilakukan penyidik itu hasilnya kemudian dicatat ke dalam BAP.

Esensi pemeriksaan terhadap terperiksa adalah pengumpulan informasi. Dalam perspektif linguistik, pemeriksaan dikatakan sebagai interograsi, yaitu aktivitas tanya jawab yang dilakukan penyidik kepada terperiksa guna mencari bukti terkait tindak pidana yang terjadi. Interograsi merupakan satu-satunya teknik pemeriksaan yang digunakan untuk mendengar keterangan dari terperiksa yang dianggap mengetahui atau setidaknya terkait dengan perkara pidana yang tengah diselidiki (Baldwin, 1993; Milne dan Bull, 1999; Shaw, 1996).

Pemeriksaan dilakukan penyidik untuk dan atas nama institusi negara. Karena itu, pemeriksaan dalam penyidikan perkara pidana dilakukan dengan memperhatikan tata cara dan kepentingan institusional. Berdasarkan hukum acara pidana, tujuan institusional pemeriksaan adalah untuk mendapatkan keterangan yang disampaikan secara sukarela dari terperiksa melalui prosedur pemeriksaan yang baku dan berlaku secara umum. Dikatakan sukarela karena terperiksa dapat menolak untuk memberikan keterangan kepada penyidik yang memeriksanya. Untuk mencapai kepentingan institusional tersebut, ketentuan perundang-undangan telah 
mengatur secara rinci tata cara pemeriksaan sebagai ketentuan yang mengikat para pihak yang terlibat dalam proses pemeriksaan (Perkap No. 14 Tahun 2012, Pasal 12, ayat 2).

Terungkapnya kasus-kasus pidana dalam sidang pengadilan selalu ditentukan oleh kelengkapan dan keakuratan keterangan yang berhasil dikumpulkan penyidik di dalam pemeriksaan. Sebaliknya, kegagalan tuntutan pidana di pengadilan tak jarang diakibatkan oleh ketidaklengkapan dan ketidakakuratan informasi yang dikumpulkan penyidik ketika melakukan pemeriksaan. Kenyataan ini menunjukkan fakta bahwa proses pemeriksaan yang diwujudkan melalui aktivitas tanya jawab merupakan hal penting yang perlu diperhatikan untuk mendukung penegakan hukum yang seadil-adilnya. Kondisi tersebut sesuai dengan pendapat para pakar, seperti George dan Clifford (1992), Inbau, Reid dan Buckley (1986), dan Shaw (1996), yang menempatkan pemeriksaan sebagai fase penting di dalam proses penyidikan perkara pidana.

Dalam konteks penyidikan perkara pidana, wawancara pemeriksaan dimaknai sebagai aktivitas yang menekankan pada pentingnya perolehan informasi dari terperiksa, baik itu saksi, ahli, maupun tersangka. Sekalipun setiap wawancara pemeriksaan dilakukan dengan ruang lingkup dan kepentingan yang berbeda-beda, namun secara keseluruhan, setiap wawancara pemeriksaan memiliki satu tujuan yang sama, yaitu mengumpulkan informasi (McGurk, Carr dan McGurk, 1993). Oleh karena itu, wawancara pemeriksaan akan selalu berorientasi pada pengumpulan informasi yang dibutuhkan penyidik guna mengungkap kejelasan sebuah perkara pidana yang sedang diselidiki.

Dalam paradigma penyidikan modern, informasi yang akurat, relevan dan lengkap hanya dapat diperoleh penyidik yang memiliki kemampuan untuk melakukan wawancara dengan baik (McElhinny, 2003). Kemampuan tersebut, dalam perspektif teori pemolisian modern, dinamakan wawancara investigatif, yaitu sebuah teknik wawancara untuk mengungkap suatu perkara pidana dengan sejelas-jelasnya dan dilakukan dengan menerapkan prinsip dasar yang menjunjung tinggi nilai-nilai kemanusiaan (Williamson, 2006; Walsh dan Milne, 2007; Shawyer, 2009; Walsh dan Bull, 2011). Untuk menguasai keterampilan tersebut, penyidik harus mampu berkomunikasi dengan baik. Sementara itu, dalam perspektif linguistik, kemampuan berkomunikasi selalu dihubungkan dengan kompetensi linguistik seseorang. Hal ini, secara tidak langsung, mengimplikasikan makna bahwa untuk menunjang kemampuan berkomunikasi, seorang penyidik harus memiliki kompetensi linguistik yang memadai.

Dalam konteks Indonesia, jumlah anak yang melakukan tindak pidana atau anak yang berkonflik dengan hukum $(\mathrm{ABH})$ grafiknya cenderung fluktuatif setiap tahun (lihat Tabel 1). Tindak pidana yang dilakukan anak-anak selama ini dirasakan telah meresahkan berbagai pihak karena sangat mengganggu hak orang lain di luar batas toleransi yang dapat diberikan. Sebenarnya, anak-anak yang melakukan tindak pidana dipandang belum dapat bertanggungjawab secara penuh atas tindakan yang dilakukannya itu. Dalam hal ini, tindak pidana yang dilakukan anak-anak mesti dipandang sebagai pengaruh eksternal yang memaksa mereka melakukan tindak pidana (Fisher, 2013; Kondori, 2015). Berikut ini adalah tabel yang menunjukkan kategori kasus kriminal yang melibatkan anak-anak Indonesia sebagai pelaku tindak pidana. 
Tabel 1. Kategori Kasus Kriminal Anak Indonesia Periode 2011-2016

\begin{tabular}{|c|c|c|c|c|c|c|c|}
\hline \multirow{2}{*}{$\begin{array}{c}\text { ANAK YANG BERKONFLIK } \\
\text { DENGAN HUKUM }\end{array}$} & \multicolumn{6}{|c|}{ Tahun } & \multirow[t]{2}{*}{$\sum$} \\
\hline & 2011 & 2012 & 2013 & 2014 & 2015 & 2016 & \\
\hline $\begin{array}{l}\text { Anak Sebagai Pelaku Kekerasan } \\
\text { Fisik (Penganiayaan, Pengeroyokan, } \\
\text { Perkelahian, dsb) }\end{array}$ & 46 & 53 & 76 & 105 & 81 & 89 & 450 \\
\hline $\begin{array}{l}\text { Anak Sebagai Pelaku Kekerasan } \\
\text { Psikis (Ancaman, Intimidasi, dsb) }\end{array}$ & 15 & 11 & 21 & 27 & 22 & 31 & 127 \\
\hline $\begin{array}{l}\text { Anak Sebagai Pelaku Kekerasan } \\
\text { Seksual (Pemerkosaan, Pencabulan, } \\
\text { Sodomi/Pedofilia, dsb) }\end{array}$ & 123 & 324 & 247 & 561 & 157 & 107 & 1519 \\
\hline Anak Sebagai Pelaku Pembunuhan & 32 & 46 & 53 & 66 & 36 & 36 & 269 \\
\hline Anak Sebagai Pelaku Pencurian & 14 & 92 & 51 & 47 & 81 & 32 & 317 \\
\hline $\begin{array}{l}\text { Anak Sebagai Pelaku Kecelakaan } \\
\text { Lalu Lintas }\end{array}$ & 9 & 86 & 48 & 58 & 52 & 51 & 304 \\
\hline $\begin{array}{l}\text { Anak Sebagai Pelaku Kepemilikan } \\
\text { Senjata Tajam }\end{array}$ & 21 & 18 & 28 & 46 & 48 & 17 & 178 \\
\hline Anak Sebagai Pelaku Penculikan & 6 & 27 & 21 & 17 & 6 & 6 & 83 \\
\hline Anak Sebagai Pelaku Aborsi & 6 & 5 & 14 & 21 & 19 & 33 & 98 \\
\hline$\sum$ & 272 & 662 & 559 & 948 & 502 & 402 & 3345 \\
\hline
\end{tabular}

Sumber: Komisi Perlindungan Anak Indonesia, Januari, 2017

\subsection{Perlindungan terhadap Hak Anak}

Secara prinsip, hukum pidana yang digunakan untuk menanggulangi $\mathrm{ABH}$ harus memperhatikan hal-hal yang terkait dengan konsep perlindungan anak. Proses pengadilan terhadap anak merupakan ultimum remidium (pilihan terakhir) dalam menyelesaikan persoalan hukum yang melibatkan ABH (Novira dan Marlina, 2013; Analiyansyah dan Rahmatillah, 2015). Hal tersebut merupakan konsesus perlindungan anak, baik yang diatur di dalam hukum Indonesia maupun hukum internasional yang telah diratifikasi oleh Pemerintah Indonesia.

Undang-Undang No. 11 Tahun 2012 yang mengatur tentang Sistem Peradilan Pidana Anak di Indonesia diberlakukan demi mewujudkan kesejahteraan anak dengan berorientasi pada kepentingan terbaik untuk anak. Dengan kata lain, ketentuan hukum itu pada hakikatnya merupakan pelindung kepentingan anak agar hak mendasar seorang anak tetap dapat terpenuhi. Deklarasi Hak-hak Anak pada 1959 yang disetujui Majelis Perserikatan Bangsa-Bangsa pada 20 November 1989 menjadi Konvensi Hak-hak Anak, perlu dirujuk sebagai prinsip dalam menyelenggarakan peradilan anak di Indonesia. Dalam hal ini, kepentingan terbaik bagi anak merupakan prinsip utama dalam menyelenggarakan peradilan anak. Sementara itu, prinsip kedua menyatakan bahwa anak sudah seharusnya menikmati perlindungan khusus dan diberikan fasilitas hukum atau upaya lainnya sehingga anak dapat membangun kualitas fisik, mental, moral, spiritual dan kepekaan sosialnya secara normal seperti anak-anak yang lain pada 
umumnya. Hal tersebut semata-mata dilakukan untuk mewujudkan nilai dasar kebebasan dan kehormatan anak (Kurniawan, 2014).

Data di bawah ini adalah beberapa contoh yang menempatkan $\mathrm{ABH}$ dalam posisi yang dirugikan sebagai tersangka perkara pidana. ABH yang proses penyelesaian hukumnya dilakukan melalui sistem peradilan pidana diposisikan tanpa perlindungan sebagai seorang anak yang keberadaannya dilindungi oleh aturan perundang-undangan. Adapun kasus-kasus yang merugikan para $\mathrm{ABH}$ itu, di antaranya, adalah sebagai berikut.

1. Kasus Muhammad Azuar alias Raju ( 8 tahun) yang harus menjalani proses peradilan sampai divonis dalam sidang pengadilan, menyisakan banyak catatan. KontraS menilai penahanan yang dilakukan terhadap Raju di tempat penahanan orang dewasa merupakan tindakan yang ceroboh dan berbahaya bagi perkembangan psikisnya. Selain itu, ada kemungkinan terjadi tindakan pelecehan seksual terhadap anak. KontraS mencatat bahwa Balai Pemasyarakatan (Bapas) tidak pernah terlibat atau dilibatkan bagi perlindungan Raju ketika proses penyidikan dan persidangan dilakukan, sehingga Bapas dalam proses hukum kasus Raju ini sama sekali tidak memberikan pertimbangan bagi hakim dalam memutuskan perkara yang dialami Raju (KontraS, 2006:24).

2. Kasus sepuluh orang anak SD yang ditahan karena tuduhan perjudian dengan menggunakan uang pecahan logam bernilai Rp500,00 di kawasan Bandara Soekarno Hatta tidak bisa diselesaikan dengan cara sederhana. Kesepuluh anak yang berjudi pada 29 Mei 2009 itu setelah ditangkap aparat polisi Polres Soekarno Hatta harus menjalani masa penahanan selama 29 hari. Dalam persidangan, Hakim Pengadilan Negeri Tangerang yang menghukum kesepuluh anak yang berjudi di Bandara Soekarno Hatta itu dinilai Komnas Perlindungan Anak Indonesia (KPAI) sangat membingungkan. Anak-anak yang menurut Hakim terbukti melakukan perjudian itu tidak mendapat hukuman pidana. Mestinya kalau tidak memberi hukuman pidana terhadap tindakan yang dilakukan anak-anak itu, Hakim tidak bisa mengatakan bahwa tindakan anak-anak itu merupakan tindakan perjudian seperti yang diatur Pasal 303 KUHP, melainkan hanya permainan saja dan bukan perjudian seperti yang dilakukan orang dewasa. Dengan putusan hakim seperi ini, anak-anak yang ditahan selama 29 hari oleh Polisi Bandara Soetta Metro patut dipertanyakan (Kompas, Juli 2009).

3. Kasus pencurian sandal jepit oleh siswa SMK berusia 15 tahun yang diadili di Pengadilan Negeri Palu, pada Selasa 20 Desember 2011 dengan delik pencurian sandal jepit milik Brigadir Satu Polisi Ahmad Rusdi Harahap, mengundang kontroversi masyarakat, termasuk masyarakat internasional. Siswa kelas 1 SMK ini didakwa dengan Pasal 362 KUHP dengan ancaman pidana lima tahun penjara. Hakim menyatakan terdakwa terbukti bersalah. Kasus ini sempat menjadi hot topic di CNN dan AL Jazeera. Kedua media tersebut seperti memperolok penegakan hukum di Indonesia. Karena dirasakan tidak adil, dukungan terhadap tersangka itu mengalir deras. Ada aksi mengumpulkan seribu pasang sandal jepit untuk korban yang sandalnya dicuri (Kompas, Januari 2012).

4. Kasus pemerkosaan seorang anak perempuan yang diduga dilakukan oleh lima orang anak di Cianjur pada 2013 yang lalu sarat dengan intimidasi dari aparat penegak hukum ketika melakukan penyidikan. Di pengadilan negeri, anak-anak itu mendapat vonis hukuman penjara selama 2,5 tahun. Namun di tingkat pengadilan tinggi, upaya banding kelima anak 
itu dikabulkan hakim, sehingga dengan alasan demi hukum kelima remaja tersebut dibebaskan (detik.com, April 2014).

Perlindungan terhadap hak anak yang menjalani proses pemidanaan merupakan isu penting yang selalu menjadi sorotan masyarakat dalam negeri dan bahkan masyarakat internasional. Perlindungan hak anak dalam proses peradilan pidana berpotensi terancam oleh buruknya kinerja aparat penegak hukum yang diberitakan bermentalitas buruk dan minimnya anggaran dan fasilitas yang dimiliki oleh negara untuk menjamin terpenuhinya hak-hak anak secara layak.

\subsection{Sistem Peradilan Pidana Anak}

Dalam rangka memberikan perlindungan terhadap hak anak, Pemerintah Indonesia telah memberlakukan aturan hukum yang terkait dengan isu anak, antara lain: (1) Undang-Undang No.4 Tahun 1979 tentang Kesejahteraan Anak, (2) Undang-Undang Nomor 39 Tahun 1999 tentang Hak Asasi Manusia, (3) Undang-Undang Nomor 23 Tahun 2002 tentang Perlindungan Anak, (4) Undang-Undang Nomor 11 Tahun 2012 tentang Sistem Peradilan Pidana Anak. Seluruh instrumen hukum tersebut, secara substansif, diarahkan untuk menjamin langkah perlindungan anak agar dapat dipastikan berjalan dengan baik.

Indonesia memiliki tradisi positif terhadap penegakan hukum perlindungan hak anak. Sebelum Indonesia merdeka, Kitab Undang-Undang Hukum Pidana Belanda yang diberlakukan Pemerintah Kolonial Belanda di Indonesia telah memuat beberapa ketentuan pidana yang secara khusus mengatur masalah tindak pidana anak (Pompe, 2005). Ketentuan pidana itu oleh para penulis Belanda disebut sebagai hukum pidana anak (juvenile system). Aturan perundangundangan yang memberi perhatian kepada anak-anak sudah dirumuskan sejak 1925 yang ditandai dengan lahirnya Stb. 1925 Nomor 647 tentang Pembatasan Kerja Anak dan Wanita. Satu tahun kemudian, yakni pada 1926, diberlakukan Stb. 1926 Nomor 87 tentang Pembatasan Anak dan Orang Muda yang Bekerja di Atas Kapal (Prasetyo, 2015).

Selain contoh-contoh yang telah disebutkan di atas, perlindungan hukum terhadap anakanak diwujudkan juga dalam beberapa aturan perundang-undangan yang lain. Setidaknya, ada dua instrumen hukum lain yang diberlakukan untuk melindungi hak anak Indonesia, yaitu: (1) Undang-Undang Nomor 20 Tahun 1999 tentang Peratifikasian Konvensi International Labor Organization tentang Usia Minimum Anak yang Diperbolehkan Bekerja, dan (2) Keputusan Presiden Nomor 39 Tahun 1990 tentang Ratifikasi Konvensi Hak Anak (yang disahkan Majelis Umum PBB pada 20 November 1989). Keppres No. 39 Tahun 1990 itu merupakan cikal bakal terbentuknya Undang-Undang Nomor 23 Tahun 2002 tentang Perlindungan Anak Indonesia.

Di setiap negara, proses peradilan anak melibatkan lembaga formal yang memiliki prosedur khusus guna melayani kepentingan ABH (Robert, 2001:11). Di Indonesia, penanganan kasus pidana $\mathrm{ABH}$ belum ditangani oleh lembaga formal yang didirikan secara khusus untuk melayani kepentingan masalah ABH. Namun demikian, fungsi formal peradilan anak dilakukan oleh aparat penegak hukum yang bertindak secara khusus untuk menangani kasus pidana $\mathrm{ABH}$ di Indonesia.

\subsection{Griffiths Questions Map}

Tujuan pemeriksaan dalam penyidikan perkara pidana adalah mengumpulkan informasi yang bernilai bukti sehingga dengan informasi tersebut peristiwa pidana yang tengah diselidiki dapat 
terungkap dengan jelas. Pemeriksaan dilakukan kepada orang-orang yang mendengar, melihat, dan mengalami terjadinya tindak pidana tersebut. Informasi dikumpulkan melalui wawancara investigatif yang dilakukan penyidik kepada terperiksa. Hasil pemeriksaan tersebut kemudian ditulis penyidik ke dalam berita acara pemeriksaaan (BAP).

Pemeriksaan yang dilakukan penyidik diarahkan untuk mengungkap hal-hal yang terkait dengan pertanyaan seperti peristiwa apa yang terjadi? Siapa yang melakukan? Bersama siapa? Kepada siapa atau pada apa dilakukan? Di mana, kapan, dan dengan cara apa tindakan itu dilakukan? (Milne dan Bull, 2006). Jenis pertanyaan yang diajukan penyidik kepada para terperiksa dalam proses pemeriksaanpidana dapat diklasifikasikan berdasarkan kategori yang termuat dalam Griffiths Question Map (GQM). Kategori pertanyaan yang dikembangkan Griffiths dan Milne (2006) digunakan sebagai instrumen evaluasi pemeriksaan yang dilakukan penyidik dalam pemeriksaan perkara pidana. Klasifikasi ragam pertanyaan di dalam GQM dikembangkan oleh para ahli psikologi kognitif yang memiliki perhatian terhadap proses pemeriksaan pidana (Heydon, 2012: 116).

GQM mengategorikan pertanyaan yang disampaikan penyidik ke dalam dua kategori besar, yaitu (1) pertanyaan produktif, yaitu pertanyaan yang disampaikan untuk menggali informasi bernilai bukti, dan (2) pertanyaan tak produktif, yaitu pertanyaan buruk yang tak mampu mengumpulkan informasi bernilai bukti terkait peristiwa pidana yang tengah diselidiki. Griffiths dan Milne (2006) menjelaskan bahwa pertanyaan produktif adalah pertanyaan yang disampaikan kepada para terperiksa untuk mengungkap informasi yang rinci dari terperiksa. Sementara itu, pertanyaan tak produktif adalah pertanyaan 'buruk' yang tidak mampu menggali informasi bernilai bukti dari terperiksa terkait dengan peristiwa pidana yang tengah diselidiki. Ketidakmampuan pertanyaan tak produktif dalam mengumpulkan informasi bernilai bukti disebabkan oleh sejumlah alasan berikut: (1) pertanyaan disampaikan dengan tidak jelas, (2) bersifat memaksa, (3) mengandung intimidasi, dan (4) merendahkan martabat terperiksa.

Pertanyaan produktif yang terdapat di dalam GQM mencakup tiga jenis pertanyaan seperti berikut.

1. Pertanyaan terbuka yang digambarkan sebagai pertanyaan yang memungkinkan disampaikannya tanggapan penuh dari terperiksa. Pertanyaan terbuka mendorong disampaikannya jawaban yang (lebih) panjang dan (lebih) akurat dari terperiksa kepada penyidik. Pertanyaan terbuka lazimnya ditandai oleh kata-kata tell, explain, describe atau dikenal juga dengan istilah TED Questions (Griffiths dan Milne, 2006: 177).

2. Pertanyaan menyelidik yang diasosiasikan sebagai pertanyaan yang membutuhkan jawaban spesifik atau akurat dari terperiksa. Pertanyaan semacam ini, biasanya, ditandai oleh kata tanya siapa, apa, mengapa, di mana, kapan, dan bagaimana atau wh-questions. Pertanyaan menyelidik disampaikan setelah penyidik mengetahui atau memiliki sejumlah informasi terkait hal yang dipertanyakan kepada terperiksa (Griffiths dan Milne, 2006: 177).

3. Pertanyaan tertutup, yaitu pertanyaan yang menuntut jawaban dengan dua opsi jawaban, yaitu ya atau tidak. Pertanyaan seperti ini disampaikan untuk mengkonfirmasi persetujuan terperiksa setelah pertanyaan terbuka dan pertanyaan menyelidik disampaikan kepadanya (Griffiths dan Milne, 2006:178). Pertanyaan tertutup secara fungsional disampaikan untuk memperkuat suatu informasi yang bernilai bukti tinggi di dalam peristiwa pidana yang sedang diselidiki. 
Sementara itu, pertanyaan tak produktif diasosiasikan sebagai pertanyaan buruk yang tak mampu mengungkap informasi bernilai bukti. Griffiths dan Milne (2006:182-183) mengungkap lima jenis pertanyaan yang termasuk dalam kategori pertanyaan tak produktif, yaitu sebagai berikut.

1. Pertanyaan inefektif, yang didefinisikan sebagai pertanyaan yang memberikan peluang kepada terperiksa untuk mengelak dan/atau memberikan jawaban yang kurang rinci. Hal tersebut dapat terjadi karena pertanyaan tersebut disampaikan pada titik yang kurang tepat sehingga terperiksa menutup diri untuk menyampaikan informasi yang diketahuinya. Pertanyaan 'Apakah Anda mengetahui orang yang menusukkan senjata ke dada korban?' yang disampaikan penyidik kepada salah seorang tersangka dalam suatu peristiwa pidana, misalnya, dapat dengan mudah disangkal jika disampaikan pada waktu yang kurang tepat. Waktu kurang tepat itu, misalnya, belum terciptanya rasa percaya dari tersangka kepada penyidik yang memeriksa, sehingga suasana pemeriksaan masih dirasakan berjarak.

2. Pertanyaan sugestif, yaitu pertanyaan yang menyarankan sebuah jawaban di dalam pertanyaan yang disampaikan kepada terperiksa. Pertanyaan 'Anda selalu bermain dengan tersangka $X$, kan?' yang disampaikan kepada salah seorang terperiksa dalam peristiwa pidana, memberikan daya sugesti kepada terperiksa untuk menjawab pertanyaan tersebut dengan jawaban yang disugestikan oleh penyidik. Pertanyaan seperti itu tergolong sebagai pertanyaan tak produktif karena informasi yang didapatkan dari si terperiksa bukan merupakan keterangan sukarela dari si terperiksa.

3. Pertanyaan berlapis, yaitu pertanyaan yang memuat sejumlah subpertanyaan yang diajukan sekaligus kepada terperiksa. Hal ini membuat terperiksa merasa kesulitan untuk memprioritaskan pertanyaan mana yang harus dijawab terlebih dulu. Pertanyaan 'Bagaimana Anda bisa sampai di tempat itu, apa yang Anda lakukan, dan pada saat seperti apa Anda memukul korban?' adalah pertanyan berlapis yang menyulitkan terperiksa untuk menjawab pertanyaan mana yang harus dijawab terlebih dahulu.

4. Pertanyaan menyudutkan, yaitu pertanyaan yang menyediakan pilihan jawaban dengan memaksa/menyudutkan terperiksa. Dengan kata lain, pertanyaan ini hanya memberi kemungkinan kepada terperiksa untuk memilih beberapa jawaban yang terpaksa harus dipilih terperiksa. Pertanyaan 'Apakah senjata tajam yang Anda bawa ini memang disiapkan untuk menusuk korban?' adalah pertanyaan yang menyudutkan terperiksa. Sebab, dengan pertanyaan itu si terperiksa hanya memiliki kesempatan untuk menjawab pertanyaan tersebut dengan jawaban ya dan tidak. Padahal, kemungkinan jawaban yang rinci dapat disampaikan terperiksa untuk menjawab pertanyaan mengapa terperiksa membawa senjata tajam ke tempat kejadian perkara (TKP).

5. Pertanyaan beropini, yaitu pernyataan yang mengandung opini atau pernyataan yang memuat stereotip tindakan si terperiksa. Pertanyaan ini dapat terjadi karena penyidik memposisikan dirinya sebagai seseorang yang sedang mengajukan pertanyaan kepada lawan atau musuh. Pertanyaan 'Menurut saya tindakan yang Anda lakukan itu termasuk sebagai upaya menghilangkan barang bukti, iya 'kan?' Pertanyaan tersebut memuat stereotip tindakan yang dilakukan terperiksa. Dalam hal ini, menurut si penyidik, tindakan si terperiksa disebut sebagai perbuatan menghilangkan barang bukti. Padahal, bisa saja tindakan si terperiksa itu untuk mengamankan barang bukti. 


\section{METODE}

Sumber data penelitian ini adalah hasil pemeriksaan polisi terhadap kasus penganiayaan yang dilakukan enam orang hingga menyebabkan seorang korban yang berusia 25 tahun tewas di lokasi kejadian. Tindakan para tersangka dijerat oleh Pasal 170 KUHP, yaitu: "Barangsiapa terang-terangan dan dengan tenaga bersama melakukan kekerasan terhadap orang atau barang, diancam dengan pidana penjara paling lama lima tahun enam bulan”. Penelitian ini menerapkan paradigma kualitatif yang berpedoman pada prosedur dan analisis teks grounded theory yang pertama kali dikembangkan oleh Strauss dan Corbin (1990) dan Glaser (1992). Paradigma penelitian kualitatif digunakan karena penelitian ini diarahkan untuk memaknai fenomena terkait penggunaan ragam pertanyaan penyidik di dalam pemeriksaan perkara pidana dengan tersangka anak yang berkonflik dengan hukum.

Analisis dalam penelitian ini diarahkan pada bahasa penyidik-tersangka di dalam pemeriksaan perkara pidana penganiayaan secara bersama-sama hingga menyebabkan korban terwas, seperti yang diatur di dalam Pasal 170 KUHP. Sumber data untuk diperolehnya data penelitian ini adalah pemeriksaan yang dilakukan penyidik kepada enam orang tersangka yang melakukan tindak pidana seperti yang diatur di dalam Pasal 170 KUHP dan masih tergolong sebagai anak-anak di bawah umur. Agar informasi yang dibutuhkan dapat diperoleh secara sistematis, penulis memanfaatkan kerangka analisis penggunaan bahasa (language use analysis) di dalam kajian ini. Data penelitian ini dianalis melalui pendekatan yang menggabungkan berbagai unsur dalam teori penggunaan bahasa dan teori yang dikembangkan dalam Griffiths Question Map (GQM).

Penerapan grounded theory dalam penelitian ini tidak dilakukan untuk menguji teori yang sudah ada, dan berlaku sebelumnya. Penelitian ini tidak bertolak dari variabel-variabel yang direduksi oleh suatu teori seperti halnya yang dilakukan dalam penelitian berparadigma kuantitatif. Strauss dan Corbin (1967:23) dan Corbin dan Strauss (1990:6) menjelaskan bahwa grounded theory merupakan metode umum yang didasarkan pada sebuah kasus yang unik, berskala mikro, berlatar alami, dan bertujuan untuk menghasilkan teori (generating theory) yang didasarkan pada data penelitian (driven by data), bukan untuk membuktikan teori (verifying theory). Data yang dianalisis bersifat emik karena data tersebut diperoleh berdasarkan penuturan, tindakan, dan pengalaman para partisipan, dalam hal ini penyidik-tersangka, ketika melakukan pemeriksaan perkara pidana. Data kemudian diidentifikasi, diberi kode, dikategorikan, dan secara konstan dibandingkan antara satu dan yang lainnya.

\section{UNIT ANALISIS DATA}

Data dalam penelitian ini adalah berita acara pemeriksaan perkara pidana $\mathrm{ABH}$ yang dilakukan oleh empat orang penyidik Polrestabes Bandung kepada enam orang tersangka yang tergolong di bawah umur. Data secara konkret berupa pertanyaan penyidik dan jawaban tersangka yang dihasilkan melalui suatu proses interogasi di Balai Pemasyarakatan Kota Bandung. Keenam orang anak diperiksa dengan status sebagai tersangka karena adanya dua alat bukti permulaan yang telah memenuhi untuk menetapkan mereka sebagai pelaku tindak pidana penganiayaan tersebut. Penyidikan perkara pidana dilakukan polisi setelah adik korban melaporkan peristiwa pidana ini kepada aparat kepolisian. Dengan demikian perkara ini termasuk ke dalam perkara yang berdelik aduan. 
Pertanyaan penyidik dan jawaban tersangka yang dihasilkan melalui pemeriksaan perkara pidana ini menjadi unit analisis data yang ditelaah dalam penelitian ini. Pertanyaan penyidik dan jawaban tersangka pada hakikatnya merupakan tuturan atau kalimat yang dikomunikasikan dalam suatu setting komunikasi yang khas, yaitu pemeriksaan polisi. Data yang dianalisis dalam penelitian ini berupa enam BAP yang dihasilkan melalui suatu proses pemeriksaan yang berlangsung selama satu hari.

\section{PEMBAHASAN}

Data yang digunakan dalam penelitian ini adalah tuturan penyidik dan tersangka yang dihasilkan dalam suatu proses pemeriksaan. Dengan memperhatikan data tersebut, analisis data akan dilakukan dengan menelaah ragam pertanyaan sesuai dengan kerangka teori yang dikembangkan dalam Griffiths Question Map. Dalam hal ini, analisis akan dibagi dengan mengklasifikasikan jenis pertanyaan ke dalam dua bagian, yaitu pertanyaan produktif dan pertanyaan tak produktif. Analisis dilakukan untuk menafsirkan pola pemeriksaan penyidik terhadap para tersangka yang masih tergolong anak-anak di bawah umur. Berikut disajikan hasil pembahasan data penelitian.

\subsection{Pertanyaan Produktif yang Disampaikan kepada Para Tersangka}

Penyidik memeriksa para tersangka untuk mengumpulkan informasi tentang bagaimana peristiwa pidana itu dilakukan. Dalam hal ini, pertanyaan penyidik diarahkan untuk mengungkap tentang peran masing-masing pelaku, seperti siapa melakukan apa, bersama siapa, kepada siapa/apa, di mana, kapan, dan dengan cara apa (Milne dan Bull, 2006). Ada enam orang tersangka yang diperiksa di dalam penyidikan perkara pidana ini. Keenam orang tersangka ini adalah anak-anak yang masih berumur antara 15 sampai dengan 17 tahun. Dari sisi pendidikan, dua orang tersangka tercatat sebagai anak putus sekolah, sedangkan empat orang lagi masih tercatat sebagai siswa kelas 2 dan 3 SMK di Bandung. Sementara itu, dari sisi catatan kriminalitas, satu orang anak tercatat pernah dipidana atas perkara pencurian dengan kekerasan (Pasal 365 KUHP), sedangkan lima orang anak lainnya baru pertama kali merasakan diproses melalui sistem peradilan pidana anak.

Pada tabel 2 disajikan sebaran ragam pertanyaan produktif yang disampaikan penyidik kepada para tersangka tindak pidana yang melakukan penganiayaan secara bersama-sama di muka umum hingga menyebabkan tewasnya seseorang sebagaimana diatur dalam Pasal 170 KUHP. Ada 112 pertanyaan produktif yang teridentifikasi di dalam BAP para tersangka. Klasifikasi ini didasarkan pada diperolehnya informasi bernilai bukti di dalam BAP keenam orang tersangka. Pertanyaan produktif disampaikan penyidik kepada para tersangka dalam suatu proses pemeriksaan yang tertutup. Dari ketiga jenis pertanyaan produktif yang berhasil teridentifikasi, pertanyaan terbuka merupakan ragam pertanyaan produktif terbanyak yang diajukan penyidik kepada tersangka, yaitu 65 pertanyaan $(58,03 \%)$. Sementara itu, pertanyaan tertutup menjadi pertanyaan terbanyak kedua dengan 33 pertanyaan $(29,46 \%)$. Pertanyaan menyelidik ada di urutan terakhir dengan 14 pertanyaan $(12,37 \%)$. 
Tabel 2. Ragam Pertanyaan Produktif dalam BAP para Tersangka Pasal 170 KUHP

\begin{tabular}{|c|c|c|c|c|}
\hline \multirow[t]{2}{*}{ Kode BAP } & \multicolumn{3}{|c|}{ JENIS PERTANYAAN PRODUKTIF } & \multirow[t]{2}{*}{$\sum$} \\
\hline & Tertutup & Terbuka & Menyelidik & \\
\hline P8.A.T1 & $\begin{array}{c}6,8,18 \\
19,22,24 \\
(n=6)\end{array}$ & $\begin{array}{c}2,7,9,11,13 \\
14,15,16,17 \\
20,21 \\
(n=11)\end{array}$ & $\begin{array}{c}4,10,12,23 \\
\quad(n=4)\end{array}$ & 24 \\
\hline P4.A.T2 & $\begin{array}{c}10,15,1618,19 \\
(n=5)\end{array}$ & $\begin{array}{c}4,5,7,8,9,11 \\
12,13,17 \\
(n=9)\end{array}$ & $\begin{array}{c}2,3 \\
(n=2)\end{array}$ & 19 \\
\hline P7.A.T3 & $\begin{array}{c}13,15,16 \\
(\mathrm{n}=3)\end{array}$ & $\begin{array}{c}3,4,5,6,7,8 \\
10,11,12,14(\mathrm{n}=10)\end{array}$ & $\begin{array}{c}2,9 \\
(\mathrm{n}=2)\end{array}$ & 16 \\
\hline P9.A.T4 & $21,22(n=2)$ & $\begin{array}{c}2,5,7,9,11 \\
12,13,14,15 \\
17,18,20 \\
(\mathrm{n}=12)\end{array}$ & $\begin{array}{c}3,10,16,19 \\
\quad(n=4)\end{array}$ & 22 \\
\hline P10.A.T5 & $\begin{array}{c}6,8,12 \\
21,23,24 \\
25,26(n=8)\end{array}$ & $\begin{array}{c}2,7,10,11,1314,15,16,18 \\
19,20,22 \\
(n=12)\end{array}$ & $\begin{array}{c}4,9 \\
(n=2)\end{array}$ & 26 \\
\hline P8.A.T6 & $\begin{array}{c}6,8,11 \\
17,18,1921,22, \\
23(n=9)\end{array}$ & $\begin{array}{c}2,4,7,9,10,12 \\
13,14,15 \\
16,20 \\
(\mathrm{n}=11)\end{array}$ & - & 23 \\
\hline$\sum$ & 33 & 65 & 14 & 112 \\
\hline
\end{tabular}

Ketika memeriksa para tersangka, penyidik terikat oleh ketentuan perundang-undangan untuk menerapkan teknik pemeriksaan guna mengumpulkan informasi dari para tersangka. Pemeriksaan merupakan hal penting dan bersifat sentral di setiap penyidikan perkara pidana (Walsh dan Oxburgh, 2008), karena hasil pemeriksaan akan berpengaruh langsung terhadap tindakan hukum lainnya yang diatur dalam sistem peradilan pidana.

Prinsip utama yang mendasari pemeriksaan adalah pemerolehan informasi secara rinci dan sebanyak mungkin dari para tersangka dengan teknik yang efektif dan tidak memaksa (Oxburgh, Myklebust, dan Grant, 2010:45). Terkait dengan hal tersebut, penyidik harus mampu mengumpulkan keterangan yang dibutuhkan dalam pemeriksaan dengan sebaik-baiknya. Dalam hal ini, keterangan yang dibutuhkan penyidik adalah informasi yang bersifat central crime details atau informasi bernilai bukti yang dapat menjelaskan terpenuhinya unsur pidana yang disangkakan kepada para tersangka secara akurat.

Berikut adalah deskripsi analisis data dan temuan penelitian terkait dengan ragam dan arah pertanyaan penyidik dalam BAP perkara pidana $\mathrm{ABH}$ dan kaitannya dengan keberhasilan penyidik dalam mengungkap informasi yang bersifat central crime details atau informasi bernilai bukti dalam perkara pidana yang tengah diselidiki. 


\subsubsection{Pertanyaan Terbuka}

Ada 65 pertanyaan terbuka dalam BAP para tersangka. Dapat dipahami bahwa hal ini terjadi karena dengan pertanyaan jenis ini penyidik dapat mengendalikan pemeriksaan untuk mendapatkan informasi yang lebih rinci dari para tersangka terkait terjadinya perkara pidana yang melibatkan para tersangka. Pertanyaan terbuka digambarkan sebagai pertanyaan yang memungkinkan disampaikannya tanggapan secara penuh dari terperiksa. Ragam pertanyaan ini mendorong disampaikannya jawaban yang (lebih) panjang dan (lebih) akurat dari tersangka. Lazimnya, pertanyaan terbuka ditandai oleh kata-kata tell, explain, describe atau dikenal juga dengan istilah TED Questions (Griffiths dan Milne, 2006:177)

Pertanyaan terbuka disampaikan kepada para tersangka untuk mendapatkan informasi akurat dan rinci mengenai hal-hal sebagai berikut.

a. Siapa yang melakukan penganiayaan, dalam hal ini siapa yang memukul (saja) dan siapa yang menusuk?

b. Apa yang menjadi masalah sehingga memicu terjadinya tindak kekerasan?

c. Di mana kejadian tersebut terjadi?

d. Dengan apa pelaku melakukan penganiayaan?

e. Mengapa pelaku melakukan hal tersebut?

f. Bagaimana kondisi korban setelah dianiaya?

g. Bilamana peristiwa tersebut terjadi?

Berikut adalah beberapa contoh pertanyaan terbuka yang disampaikan para penyidik di dalam BAP Tersangka.

\section{Ekstrak 1}

11. Agar saudara terangkan siapa yang telah menjadi korbannya dalam peristiwa tersebut serta siapa saja yang telah melakukan pengeroyokan tersebut?

11. Adapun yang telah menjadi korbannya yaitu 1 (satu) orang laki-laki yang saya ketahui bernama Sdr. B, tapi ga saya kenal cuma tahu saja. Sedangkan yang telah melakukan pengeroyokan terhadap korban tersebut yaitu kurang lebih sekitar 10 (sepuluh) orang yaitu saya sendiri, Sdr. Ji, Sdr. J alias Jn, Sdr. A, Sdr. R, Sdr. L, Sdr. Rn, Sdr. Y, Sdr. D, dan Sdr. Ri

Dalam ekstrak 1, penyidik menyampaikan pertanyaan terkait siapa yang menjadi korban dan pelaku pengeroyokan terhadap korban. Pertanyaan tersebut sebenarnya menunjukkan ciri pertanyaan menyelidik karena adanya kata tanya siapa yang digunakan dalam pertanyaan tersebut. Namun, di awal pertanyaan itu terdapat kata terangkan (explain), yang menuntut si tersangka untuk menerangkan siapa korban dan pelaku tindak pidana penganiayaan ini. Dengan ragam pertanyaan tersebut, penyidik menuntut Tersangka 1 untuk memberikan jawaban yang lebih panjang dan rinci sesuai dengan yang diketahuinya, tidak sekadar menyebutkan nama seperti yang dituntut melalui kata tanya siapa. Arah pertanyaan yang diajukan penyidik disampaikan untuk mengungkap unsur barang siapa dalam Pasal 170 KUHP. Dalam ekstrak 1, terlihat bahwa Tersangka 1 memenuhi harapan penyidik untuk mendapatkan keterangan terkait pelaku dan korban. Dalam hal ini, Tersangka 1 menerangkan bahwa dirinya mengetahui nama korban tapi tidak mengenalnya. Hal ini merupakan bukti bahwa Tersangka 1 tidak sekadar menyebutkan nama saja, tapi juga memberikan keterangan terkait perkenalannya dengan korban. 
Tersangka 1 secara terbuka menyebutkan empat nama teman-temannya yang dikatakan ikut terlibat dalam peristiwa penganiayaan yang mereka lakukan. Dalam hal ini, Tersangka 1 menyebut Sdr. A, Sdr. Ri, Sdr. L, dan Sdr. Rn ikut terlibat dalam penganiayaan kepada korban. Namun, keterangan Tersangka 1 tidak ditindaklanjuti penyidik untuk mengkonfrontasi dengan keempat orang yang dikatakan terlibat dalam peristiwa penganiayaan tersebut. Keempat nama yang diterangkan oleh Tersangka 1 ikut terlibat dalam penganiayaan tidak menjadi tersangka dalam perkara pidana ini. Status keempat orang yang disebutkan namanya oleh Tersangka 1 hanyalah sebagai saksi.

Selanjutnya, pertanyaan terbuka yang ditujukan kepada Tersangka 3 diarahkan untuk mengetahui dengan cara bagaimana para tersangka melakukan penganiayaan kepara korban. Pertanyaan tersebut dapat dilihat dalam ekstrak 2 seperti berikut.

\section{Ekstrak 2}

6. Jelaskanlah dengan cara bagaimana Sdr melakukan pemukulan dan penusukan terhadap korban tersebut?

6. Saya melakukan pemukulan terhadap korban sebanyak 2 (dua) kali yang diarahkan kebagian muka dan dada korban dengan menggunakan tangan kosong pada saat korban terjatuh akibat dipukul oleh teman-teman saya, sementara saya melakukan penusukan terhadap korban sebanyak 1 (satu) kali yang ditujukan kebagian dada sebelah kiri dengan menggunakan pisau belati.--

Dalam ekstrak 2, pertanyaan terbuka yang diajukan penyidik kepada Tersangka 3 ditandai dengan penggunakan kata jelaskanlah (explain). Melalui pertanyaan ini arah pertanyaan penyidik adalah untuk mengungkap tentang cara yang dilakukan tersangka sehingga menyebabkan korban meninggal dunia. Pertanyaan tersebut disampaikan untuk memenuhi unsur melakukan kekerasan seperti yang diatur dalam Pasal 170 KUHP. Sebelum pertanyaan seperti dalam ekstrak 2 disampaikan, Tersangka 3 telah mengakui bahwa dirinyalah yang melakukan penusukan terhadap korban. Atas dasar itu, penyidik dengan pertanyaan terbuka ingin mendapatkan keterangan yang lebih rinci tentang cara yang dilakukan Tersangka 3 ketika menusuk bagian dada kiri korban. Informasi tersebut merupakan central criminal details, yaitu mempertegas terpenuhinya unsur dilakukannya tindak kekerasan oleh tersangka secara bersamasama.

Selain itu, penyidik perlu mendapatkan keterangan terkait tindakan yang dilakukan oleh Tersangka 3 sehingga menyebabkan korban meninggal dunia. Hasil visum dan autopsi menunjukkan bahwa korban meninggal akibat luka tusuk di bagian dada sebelah kiri. Karena itu, penyidik perlu mengetahui informasi yang akurat tentang pelaku penusukan kepada korban. Hal tersebut merupakan dasar untuk pembebanan dan pertanggunjawaban pidana yang diatur Pasal 170 KUHP. Walaupun penganiayaan ini dilakukan oleh enam orang tersangka, hukuman yang dibebankan tidak disamaratakan bagi seluruh tersangka. Dalam hal ini, tersangka yang menusuk korban dapat dipastikan akan mendapatkan hukuman yang jauh lebih lama dibandingkan dengan tersangka lainnya yang hanya melakukan pemukulam terhadap korban.

Selain pertanyaan terbuka seperti pada ekstrak 2, penyidik menyampaikan pertanyaan terbuka lainnya seperti yang tersaji dalam ekstrak 3 berikut. Pertanyaan terbuka dalam ekstrak 3 disampaikan untuk menggali tempat dan waktu dilakukannya tindak penganiayaan kepada korban. 


\section{Ekstrak 3}

9. Katakan oleh Sdr. waktu dan tempat Sdr. melakukan penganiayaan sampai korban meninggal dunia? Dan bersama siapa Sdr. melakukannya?-

9. Kejadian itu terjadi pada hari Rabu tanggal 23 September 2015 sekitar jam. 22.30 Wib di depan Alfhamart deket pedagang sate Jl. X Kec. X Kota C dan saya melakukan penganiayaan itu bersama dengan sdr Jn, sdr Ji, sdr Rn, sdr E, sdr Y, sdr.A, dan sdr R.

Dalam ekstrak 3, penyidik menyampaikan pertanyaan terbuka yang ditandai dengan kata katakan (tell). Pertanyaan tersebut diarahkan untuk mengungkap tempat dan waktu terjadinya perkara pidana tersebut. Fungsi pertanyaan tersebut adalah untuk mengetahui terpenuhinya unsur di muka umum yang terdapat di dalam Pasal 170 KUHP. Dalam hal ini, apakah tempat terjadinya perkara tersebut merupakan tempat yang tergolong di muka uтит ataukah bukan? Sebab, jika penganiayaan tersebut tidak dilakukan di tempat umum, maka pasal yang digunakan untuk menjerat para tersangka tidak bisa menggunakan Pasal 170 KUHP, melainkan Pasal 351 KUHP. Selain itu, pembebanan pidana akan berbeda bergantung waktu terjadinya tindak pidana tersebut. Tindak pidana yang dilakukan pada siang hari pembebanan hukumnya akan berbeda dengan tindak pidana yang dilakukan di malam hari.

\subsubsection{Pertanyaan Tertutup}

Ada 33 pertanyaan tertutup atau $29,46 \%$ dari total pertanyaan produktif yang ada di dalam BAP para tersangka. Dalam BAP tersangka, pertanyaan tertutup tidak akan bermakna untuk disampaikan kepada para tersangka. Sebab, penyidik membutuhkan keterangan rinci dari para tersangka tentang terjadinya tindak pidana. Karena itu, dapat dipahami jika ditemukan lebih sedikit pertanyaan tertutup dibandingkan pertanyaan terbuka. Pertanyaan tertutup disampaikan penyidik untuk mengkonfirmasi sejumlah hal yang sudah diketahui para tersangka.

Umumnya, pertanyaan tertutup disampaikan kepada para tersangka untuk memastikan dan mengkonfirmasi kebenaran atau ketidakbenaran informasi mengenai hal-hal sebagai berikut.

a. Identitas para tersangka.

b. Pemahaman tersangka.

c. Pengakuan yang dinyatakan tersangka.

d. Keterangan yang disampaikan tersangka lainnya.

Ekstrak 4 memuat contoh pertanyaan tertutup yang disampaikan kepada tersangka dalam perkara pidana ini dengan tujuan untuk mengkonfirmasi pemahaman tersangka atas tindakan yang dilakukan penyidik.

\section{Ekstrak 4}

2. Apakah sebelumnya Sdr. sudah mengerti maksud dan tujuannya sehingga dilakukan pemeriksaan sekarang ini, jika mengerti dalam perkara apa?

2. Ya, sebelumnya saya sudah mengerti maksud dan tujuannya dilakukan pemeriksaan yaitu untuk memberikan keterangan selaku tersangka dalam perkara tindak pidana Penganiayaan dan/atau pembunuhan.

Pertanyaan dalam ekstrak 4 adalah pertanyaan tertutup yang menyediakan dua opsi jawaban, yaitu ya dan tidak. Dalam hal ini, penyidik sedang mengkonfirmasi tersangka terkait 
pemahamannya menjalani pemeriksaan. Pertanyaan ini wajib disampaikan penyidik sebagai ketentuan formal yang diatur dalam Pasal 27 ayat (1) Perkap No. 8 tahun 2009 tentang Implementasi Prinsip dan Standar Hak Asasi Manusia dalam Penyelenggaraan Tugas Pokok Polri, yaitu penyidik wajib memeriksa kesiapan dan pemahaman terperiksa di dalam acara pemeriksaan.

Untuk menjawab pertanyaan ini, tersangka sesungguhnya cukup menjawab dengan pilihan jawaban ya atau tidak. Namun, pada kenyataannya, dalam ekstrak 4 terdapat keterangan tambahan seperti berikut: “... mengerti maksud dan tujuannya dilakukan pemeriksaan yaitu untuk memberikan keterangan selaku tersangka dalam perkara tindak pidana penganiayaan dan/atau pembunuhan”. Padahal, dalam wawancara pemeriksaan yang dilakukan, tersangka tidak menyampaikan keterangan seperti itu. Dalam hal ini, tersangka hanya mengatakan kalimat "Ya, saya mengerti". Tambahan keterangan itu dilakukan penyidik. Fenomena tersebut dikatakan sebagai diskrepansi (ketidakcocokan) informasi karena adanya penambahan keterangan yang dilakukan penyidik terhadap jawaban yang disampaikan oleh tersangka. Sesungguhnya, penambahan keterangan dilakukan juga oleh penyidik dalam jawaban pertanyaan lainnya. Aziz, dkk. (2013) menyebut fenomena ini sebagai frasa pembuka untuk konfirmasi. Secara substansif tambahan keterangan itu bersifat pheriperal crime detail yang tidak terkait dengan unsur utama di dalam Pasal 170 KUHP.

Dalam BAP ditemukan satu pertanyaan tertutup yang tidak tepat penggunaannya, seperti yang terlihat dalam ekstrak 5 berikut.

\section{Ekstrak 5}

5. Sesuai dengan hak saudara sebagai Tersangka, apakah dalam pemeriksaan sekarang ini saudara akan didampingi oleh penasehat Hukum/Pengacara?-

5. Dalam pemeriksaan sekarang ini saya tidak akan menggunakan hak saya untuk didampingi penasehat Hukum atau Pengacara, dan akan dihadapi sendiri. (Sesuai hak dan ancaman hukuman terhadap tersangka, berdasarkan Undang-Undang yaitu wajib didampingi Pengacara atau Penasehat Hukum atau mendapatkan bantuan hukum, penyidik menyediakan bantuan hukum dari Kantor Hukum POSBAKUM DPC IKADIN Bandung untuk mendampingi tersangka).------

Ekstrak 5 mempertanyakan apakah tersangka akan didampingi oleh pengacara atau tidak? Jawaban tersangka atas pertanyaan tersebut adalah tidak. Namun dalam kolom jawaban tersangka, penyidik menuliskan keterangan seperti berikut: "Sesuai hak dan ancaman hukuman terhadap tersangka, berdasarkan Undang-Undang, yaitu wajib didampingi Pengacara atau Penasehat Hukum atau mendapatkan bantuan hukum, penyidik menyediakan bantuan hukum dari Kantor Hukum POSBAKUM DPC IKADIN Bandung untuk mendampingi tersangka". Hal ini berarti bahwa, sesungguhnya, tersangka wajib untuk didampingi oleh pengacara selama menjalani pemeriksaan. Karena itu, pertanyaan tersebut menjadi tidak efektif untuk disampaikan kepada tersangka. Sebab, pertanyaan tersebut tidak akan berpengaruh terhadap keharusan tersangka didampingi oleh pengacara.

Semestinya, penyidik menyampaikan pemberitahuan bahwa dalam pemeriksaan ini tersangka harus didampingi pengacara apabila tidak mampu menyediakan pengacara secara mandiri, penyidik akan menyediakan pengacara bagi tersangka. Sebab, dalam UU No. 11 Tahun 2012 seorang $\mathrm{ABH}$ yang menjalani proses peradilan pidana wajib didampingi oleh pengacara. 


\subsubsection{Pertanyaan Menyelidik}

Dalam BAP para tersangka, ditemukan 12 pertanyaan menyelidik atau sebesar 12,37\% dari total pertanyaan produktif yang terdapat di dalam BAP para tersangka. Pertanyaan menyelidik merupakan pertanyaan yang membutuhkan jawaban spesifik/akurat dari terperiksa. Pertanyaan semacam ini biasanya ditandai dengan kata tanya siapa, apa, mengapa, di mana, kapan, dan bagaimana atau sering juga disebut sebagai wh-questions. Pertanyaan ini disampaikan setelah penyidik mengetahui atau memiliki sejumlah informasi terkait hal yang ditanyakan kepada terperiksa (Griffiths dan Milne, 2006:178). Jumlah pertanyaan menyelidik jauh lebih sedikit dibandingkan dengan ragam pertanyaan produktif lainnya karena keterangan terkait unsur pokok tindak pidana yang terjadi sudah diperoleh dari para saksi yang dinilai jauh lebih objektif menilai tindakan para tersangka dibandingkan pengakuan tersangka sendiri.

Sama seperti halnya pertanyaan terbuka, pertanyaan menyelidik disampaikan penyidik kepada para terangka untuk mengungkap informasi yang terkait dengan unsur pokok yang terdapat di dalam Pasal 170 yang digunakan untuk menjerat para tersangka, yaitu:

a. Siapa yang melakukan penganiayaan, dalam hal ini siapa yang memukul (saja) dan siapa yang menusuk?

b. Apa yang menjadi masalah sehingga memicu terjadinya tindak kekerasan?

c. Di mana kejadian tersebut terjadi?

d. Dengan apa pelaku melakukan penganiayaan?

e. Mengapa pelaku melakukan hal tersebut?

f. Bagaimana kondisi korban setelah dianiaya?

g. Bilamana peristiwa tersebut terjadi?

Hal yang membedakan pertanyaan menyelidik dan pertanyaan terbuka hanya terletak pada masalah kerinciannya saja. Dalam hal ini pertanyaan terbuka lebih menuntut jawaban yang lebih rinci dan panjang, sementara pertanyaan menyelidik menuntut jawaban yang lebih akurat. Ekstrak 6 berikut adalah contoh pertanyaan menyelidik yang terdapat di dalam BAP para tersangka.

\section{Ekstrak 6}

11. Siapa yang memulai di antara teman-teman Sdr. untuk mendatangi korban di lokasi kejadian?

11. Yang mendatangi korban ke lokasi kejadian yaitu Sdr. E dan Sdr. Ri.--------

Ekstrak 6 memuat pertanyaan menyelidik yang disampaikan penyidik untuk mengungkap informasi tentang siapa di antara para tersangka yang pertama kali berinisiatif menemui korban. Pertanyaan tersebut tepat disampaikan kepada Tersangka 4. Sebab, Tersangka 4 pasti memiliki latar belakang pengetahuan tentang kejadian melakukan peganiayaan kepada korban. Oleh karena itu, berdasarkan pengetahuannya Tersangka 4 menjawab bahwa yang pertama kali mendatangi korban ke lokasi kejadian adalah dua orang temannya, yaitu Sdr. E (Tersangka 1) dan Sdr. Ri (Tersangka 3). Dalam jawaban tersangka, terdapat frasa pengantar untuk mengonfirmasi yang ditambahkan penyidik dalam kolom jawaban tersangka 4, yaitu yang mendatangi korban ke lokasi kejadian. Fenomena ini kerap terjadi karena besarnya kuasa penyidik untuk mendefinisikan pernyataan tersangka ke dalam berita acara pemeriksaan (lihat Wakfield, 2014:127). 
Di samping itu, pertanyaan menyelidik ditemukan juga dalam BAP tersangka dengan tujuan untuk mengetahui latar belakang atau motif para tersangka melakukan penganiayaan kepada korban. Hal tersebut dapat dilihat dalam ekstrak 7 seperti berikut.

\section{Ekstrak 7}

19. Apakah Sdr. sebelumnya memiliki permasalahan dengan korban?

19. Yang saya dengar bahwa sebelumnya ada permasalahan antara Sdr. Y dengan korban bernama Sdr. B, dimana awal permasalahan tersebut yaitu pada saat Sdr. Y dengan Sdr. J menggunakan sepeda motor merk Suzuki Smash milik Sdr. Y melintas didepan Alfa Mart Jl. X Kota Bandung dengan menggerung-gerungkan sepeda motornya, lalu korban $B$ meneriaki Sdr. Y dan Sdr. Ji dengan kata-kata kasar "ANJING" sambil akan memukul Sdr. Y, namun waktu itu tidak sampai terjadi perkelahian, melainkan Sdr. Y dan Sdr. Ji langsung pergi dan menceritakan kejadian tersebut kepada rekan-rekan lainnya di tempat berkumpul yaitu di Jl. X Kec. X Kota Bandung, sehingga waktu itu Sdr. E dan Sdr. R mencoba mendatangi korban $B$ dengan menggunakan sepeda motor milik Sdr. E merk Honda Revo yang maksudnya untuk meluruskan permasalahannya dengan korban B, namun disaat Sdr. E dan Sdr. R pergi, kemudian Sdr. Y pergi menyusul Sdr. $E$ dan Sdr. $R$ dengan menggunakan sepeda motor merk Suzuki Smash miliknya sambil mengatakan "moal bener euy aya bahan piributeun" (Tidak akan benar euy ini bakal jadi ribut), yang akhirnya saya dan rekan yang lainya pun ikut menyusulnya dengan menggunakan sepeda motor milik Sdr. Ri dan Sdr. Rn.

Ekstrak 7 memuat pertanyaan yang disampaikan penyidik kepada tersangka untuk mengungkap keterangan secara akurat tentang motif atau alasan yang memicu terjadinya penganiayaan di antara para tersangka dan korban. Hal ini penting untuk diungkap guna mengetahui ada tidaknya unsur perencanaan pembunuhan terhadap korban. Jika terdapat perencanaan atau niat jahat untuk menghabisi korban sebelum penganiayaan terjadi, maka pasal yang digunakan untuk menjerat para tersangka akan berubah menjadi pasal pembunuhan berencana, yaitu Pasal 340 KUHP. Dengan memperhatikan jawaban tersangka dapat diketahui bahwa penganiayaan yang menyebabkan korban meninggal dunia terjadi secara spontan atau tanpa ada perencanaan terlebih dahulu untuk menghabisi korban. Secara spesifik, penyidik berhasil mengungkap hal penting tentang ada tidaknya unsur perencanaan dalam tindak penganiayaan yang dilakukan para tersangka.

\subsection{Pertanyaan Tak Produktif yang Disampaikan kepada Para Tersangka}

Pertanyaan tak produktif ditemukan di dalam BAP para tersangka sebanyak 18 pertanyaan atau $13,84 \%$ dari jumlah keseluruhan pertanyaan yang disampaikan kepada tersangka. Sebaran pertanyaan tak produktif yang ditemukan di dalam BAP para tersangka dapat dilihat dalam Tabel 3 seperti berikut. 
Tabel 3. Ragam Pertanyaan Tak Produktif dalam BAP para Tersangka Pasal 170 KUHP

\begin{tabular}{|c|c|c|c|c|c|}
\hline \multirow[t]{2}{*}{ Kode BAP } & \multicolumn{4}{|c|}{ JENIS PERTANYAAN TAK PRODUKTIF } & \multirow{2}{*}{$\Sigma$} \\
\hline & Sugestif & Multiple & Menyudutkan & Beropini & \\
\hline P8.A.T1 & $\begin{array}{c}3 \\
(n=1)\end{array}$ & $\begin{array}{c}1,5 \\
(\mathrm{n}=2)\end{array}$ & - & - & 3 \\
\hline P4.A.T2 & - & $\begin{array}{l}1,6,14 \\
(\mathrm{n}=3)\end{array}$ & - & - & 3 \\
\hline P7.A.T3 & - & $\begin{array}{c}1 \\
(n=1)\end{array}$ & - & - & 1 \\
\hline P9.A.T4 & $\begin{array}{c}6 \\
(n=1)\end{array}$ & $\begin{array}{c}1 \\
(n=1)\end{array}$ & $\begin{array}{c}8 \\
(n=1)\end{array}$ & $\begin{array}{c}4 \\
(n=1)\end{array}$ & 4 \\
\hline P10.A.T5 & $\begin{array}{c}3 \\
(n=1)\end{array}$ & $\begin{array}{l}1,5,17 \\
(\mathrm{n}=3)\end{array}$ & - & - & 4 \\
\hline P8.A.T6 & $\begin{array}{c}3 \\
(\mathrm{n}=1)\end{array}$ & $\begin{array}{c}1,5 \\
(\mathrm{n}=2)\end{array}$ & - & - & 3 \\
\hline$\sum$ & 4 & 12 & 1 & 1 & 18 \\
\hline
\end{tabular}

Pertanyaan tak produktif merupakan pertanyaan yang tergolong sebagai pertanyaan buruk, yaitu pertanyaan yang tak mampu menggali informasi bernilai bukti. Dalam BAP para tersangka, ditemukan empat jenis pertanyaan tak produktif yang disampaikan kepada para tersangka. Dari 18 pertanyaan tak produktif yang ditemukan di dalam BAP para tersangka, sebanyak 12 pertanyaan $(66,68 \%)$ tergolong sebagai pertanyaan berlapis, empat pertanyaan tergolong sebagai pertanyaan sugestif $(22,22 \%)$, satu pertanyaan tergolong sebagai pertanyaan menyudutkan $(5,55 \%)$, dan satu pertanyaan terakhir sebagai pertanyaan beropini $(5,55 \%)$. Berikut adalah deskripsi tiap-tiap pertanyaan tak produktif yang ditemukan di dalam BAP para tersangka.

\subsubsection{Pertanyaan Berlapis}

Pertanyaan berlapis, yaitu pertanyaan yang memuat sejumlah subpertanyaan yang diajukan secara serentak kepada terperiksa. Hal ini membuat tersangka merasa kesulitan untuk memprioritaskan pertanyaan mana yang harus dijawab terlebih dulu. Pertanyaan berlapis ditemukan dalam BAP para tersangka sebanyak 12 pertanyaan (66,68\%). Berikut adalah contoh pertanyaan berlapis yang disampaikan penyidik kepada para tersangka di dalam BAP.

\section{Ekstrak 8}

7. Agar Sdr jelaskan apakah sebelumnya Sdr kenal dengan korban yang bernama $\mathbf{X}$, jika kenal sejak kapan dan dimana serta dalam hubungan apa, jelaskan sehingga bisa mengetahui tindak pidana penganiayaan dan atau pembunuhan tersebut ?-----

7. Ya, sebelumnya saya tidak kenal dengan korban yang bernama sdr $X$. Dan saya bisa mengetahui karena saya bersama teman saya yang melakukan tindak pidana tersebut.

Dalam ekstrak 8 terlihat ada pertanyaan berlapis yang harus dijawab tersangka, yaitu pertanyaan yang memuat lebih dari satu pertanyaan. Pertanyaan semacam ini menyulitkan tersangka sehingga sulit untuk diandalkan sebagai keterangan bernilai bukti karena dihasilkan 
melalui prosedur yang merugikan tersangka. Namun, terperiksa tetap bisa menjawab pertanyaan tersebut secara jelas dan tepat. Sebab, dalam menyampaikan pertanyaan tersebut kepada tersangka, penyidik melakukannya secara terpisah atau tidak secara bersamaan. Pertanyaan tersebut disampaikan satu per satu, sehingga memungkinkan tersangka menjawab pertanyaan tersebut.

Lapis pertanyaan pertama di dalam ekstrak 8, yaitu apakah tersangka mengenal korban atau tidak? Kemudian, lapis pertanyaan kedua masih logis untuk disampaikan di dalam satu pertanyaan karena tidak memiliki jarak topik (topic distance) dengan lapis pertanyaan pertama. Artinya, materi pertanyaan lapis pertama dan kedua masih berhubungan. Selanjutnya, pertanyan lapis ketiga, tersangka diminta menjelaskan mengapa bisa mengetahui tindak pidana penganiayaan dan/atau pembunuhan tersebut? Pertanyaan lapis ketiga tidak berhubungan secara topik dengan lapis pertanyaan pertama dan kedua. Pertanyaan lapis ketiga disampaikan kepada tersangka untuk mengetahui informasi dari mana tersangka mengetahui terjadinya tindak pidana penganiayaan dan/atau pembunuhan. Pertanyaan lapis ketiga kurang relevan disampaikan kepada Tersangka 5. Sebab, sebagai subjek pengalam (experiencer), tersangka pasti mengetahui terjadinya tindak pidana penganiayaan dan/atau pembunuhan itu berdasarkan pengalamannya sendiri.

Dengan adanya bukti linguistik seperti yang terdapat di dalam ekstrak 8, pertanyaan penyidik tergolong juga sebagai pertanyaan inefektif. Semestinya, penyidik tidak menyampaikan pertanyaan tersebut secara berlapis. Semestinya pertanyaan tersebut dibagi ke dalam beberapa bentuk pertanyaan agar jawaban dari tersangka dapat disampaikan secara beraturan dan terarah pada tiap-tiap pokok pertanyaan. Dengan demikian, pertanyaan tersebut tidak akan menjadi pertanyaan ineffective. Dengan ragam pertanyaan seperti ini, ekstrak 8 hanya mampu mengungkap pheriperal crime detail atau keterangan yang tidak bernilai bukti. Sebab, keterangan dari tersangka tidak mampu mengungkap unsur pidana dalam Pasal 170 yang dipersangkakan kepada para tersangka.

\subsubsection{Pertanyaan Sugestif}

Pertanyaan sugestif di dalam BAP para tersangka ditemukan sebanyak empat pertanyaan $(22,22 \%)$. Pertanyaan sugestif merupakan pertanyaan yang menyarankan sebuah jawaban di dalam pertanyaan yang disampaikan kepada tersangka. Pertanyaan seperti ini tergolong sebagai pertanyaan tak produktif karena informasi yang didapatkan dari tersangka bukan merupakan keterangan yang diperoleh secara sukarela dan tidak berasal dari pengakuan tersangka, melainkan dari penyidik. Dalam ekstrak 9 terlihat jenis pertanyaan sugestif yang disampaikan kepada Tersangka 6.

\section{Ekstrak 9}

8. Apa yang menyebabkan sehingga Sdr. ditangkap oleh anggota polisi yang berbaju preman tersebut?-

8. Yang menyebabkan sehingga saya ditangkap oleh anggota karena telah melakukan penganiayaan sampai korban meninggal dunia.

Pertanyaan di dalam ekstrak 9 memperlihatkan adanya sugesti dari penyidik kepada Tersangka 6 untuk mengakui bahwa dirinya ditangkap anggota kepolisian. Dalam hal ini, tersangka telah diberikan sugesti bahwa dirinya ditangkap. Padahal, dirinya menyerahkan diri setelah melarikan diri keluar kota Bandung selama empat hari. Hal ini menunjukkan sugesti 
penyidik kepada tersangka bahwa tindakan yang dilakukan anggota kepolisian kepada dirinya adalah penangkapan. Padahal, hal yang terjadi dengan sesungguhnya adalah menyerahkan diri dengan diantar kedua orang tuanya ke kantor polisi. Namun demikian, tidak selamanya pertanyaan sugestif tergolong sebagai pertanyaan tak produktif. Ada sejumlah jenis pertanyaan sugestif lainnya yang bisa digunakan sebagai pertanyaan produktif, sepanjang penyidik memiliki bukti awal untuk mengkonfirmasi data yang sebelumnya sudah diperoleh penyidik dari alat bukti dan keterangan lainnya. Dengan demikian, pertanyaan sugestif bisa juga menghasilkan informasi bernilai bukti yang bagus.

\subsubsection{Pertanyaan Menyudutkan}

Pertanyaan menyudutkan di dalam BAP para tersangka hanya ditemukan satu pertanyaan saja $(5,55 \%)$. Pertanyaan menyudutkan merupakan pertanyaan yang menyediakan pilihan jawaban yang bersifat menyudutkan tersangka. Dengan kata lain, pertanyaan ini hanya memberi kemungkinan kepada tersangka untuk memilih atau mengakui beberapa jawaban yang disediakan oleh penyidik. Pertanyaan menyudutkan hanya menyediakan kesempatan kepada tersangka untuk menjawab pertanyaan tersebut dengan jawaban ya dan tidak. Padahal, kemungkinan jawaban rinci dapat disampaikan oleh tersangka untuk menjawab pertanyaan yang disampaikan penyidik kepada tersangka.

Ekstrak 10 berikut ini adalah contoh pertanyaan menyudutkan yang disampaikan penyidik kepada tersangka.

\section{Ekstrak 10}

3. Orang bawa senjata kaya kamu pasti kalau bawa samurai ke TKP untuk dipakai melukai orang, iya'kan?

3.Tidak, saya bawa samurai ke tempat itu untuk menakut-nakuti orang agar engga macem-macem ama temen saya bukan untuk melukai orang lain.

Dalam ekstrak 10, penyidik menyudutkan tersangka untuk memberikan jawaban sesuai dengan opsi jawaban yang disediakannya, yaitu ya atau tidak. Semestinya, pertanyaan semacam ini disampaikan melalui pertanyaan menyelidik agar diperoleh jawaban yang lebih rinci dan jelas dari tersangka. Penyidik perlu menggali secara rinci terkait alasan tersangka membawa samurai ke TKP. Dalam Ekstrak 10, walau penyidik menyudutkan tersangka dengan pertanyaan yang disampaikannya, tersangka tidak sekadar menjawab pertanyaan tersebut dengan salah satu opsi jawaban ya atau tidak. Dalam hal ini, tersangka memberikan alasan mengapa dirinya membawa samurai ke TKP. Fenomena tersebut menunjukkan adanya kesadaran dari tersangka bahwa opsi jawaban yang disediakan penyidik merugikan. Selain itu, daya paksa pertanyaan tersebut untuk menyudutkan tersangka sangatlah kecil. Dalam hal ini, sekalipun penyidik telah menyudutkan tersangka bahwa samurai yang dibawa ke TKP adalah untuk melukai orang lain, tersangka tidak menyetujui dengan asumsi penyidik.

\subsubsection{Pertanyaan Beropini}

Pertanyaan beropini dalam BAP para tersangka hanya ditemukan satu pertanyaan saja $(5,55 \%)$, yaitu dalam BAP Tersangka 5. Pertanyaan beropini merupakan pernyataan yang mengandung opini atau pernyataan terkait stereotip tindakan tersangka. Pertanyaan ini dapat terjadi karena penyidik memosisikan dirinya sebagai seseorang yang sedang mengajukan pertanyaan kepada 
lawan atau musuh. Berikut adalah contoh pertanyaan beropini yang terdapat di dalam BAP tersangka.

\section{Ekstrak 11}

9. Saudara menerangkan bahwa setelah penganiayaan terjadi, Sdr. pergi ke luar kota, mengapa Sdr. kabur ke luar kota, Sdr. takut dihukum, ya?

9. Tidak, saya ke Majalengka untuk menghindari orang tua saya yang pasti marah kalau tau saya ikut mengeroyok orang.

Dalam ekstrak 11, terlihat adanya opini dari penyidik yang termuat di dalam pertanyaannya, yaitu dengan mengopinikan bahwa tindakan tersangka adalah kabur karena takut dihukum. Opini ini menggiring tersangka untuk mengakui dan memahami bahwa tindakan yang dilakukannya itu adalah kabur. Sesungguhnya, hal tersebut bukanlah perkataan tersangka, melainkan opini penyidik. Dalam hal ini, bisa saja tersangka memahami bahwa apa yang dilakukan dirinya itu adalah tindakan untuk menghindar amarah orang tua, bukan kabur menghindari hukuman pidana. Pertanyaan beropini jelas merupakan pertanyaan yang tak produktif karena pertanyaan ini menggali informasi yang tidak didasarkan pada pengakuan tersangka, tetapi merupakan opini penyidik yang disampaikan secara sepihak.

\section{SIMPULAN}

Berdasarkan hasil analisis data dalam studi ini, dapat disimpulkan beberapa hal seperti berikut.

1. Ragam pertanyaan produktif ditemukan lebih banyak dibandingkan pertanyaan tak produktif di dalam BAP para tersangka. Hal ini mengindikasikan makna bahwa penyidik telah menerapkan prosedur pemeriksaan yang benar, khususnya dalam menggunakan strategi bertanya kepada para tersangka.

2. Pertanyaan terbuka ditemukan sebagai jenis pertanyaan produktif yang paling banyak disampaikan kepada para tersangka, dibandingkan pertanyaan tertutup dan pertanyaan menyelidik. Hal ini menunjukkan makna bahwa penyidik lebih membutuhkan keterangan yang lebih rinci dan detil, dibandingkan jawaban yang akurat dan terkonfirmasi dari para tersangka. Hal ini dilakukan bukan tanpa alasan. Melalui pertanyaan terbuka, penyidik tengah berupaya mencari kesesuaian alat bukti dan keterangan saksi dengan pengakuan tersangka guna membuktikan tindakan pidana yang sebenar-benarnya terjadi.

3. Pelanggaran terhadap perlindungan hak anak di dalam pemeriksaan memang nampak terlihat pada penggunaan bentuk pertanyaan yang disampaikan penyidik kepada para tersangka, seperti memberikan opini, sugesti, menyudutkan, dan memberikan pertanyaan berlapis. Ditemukannya ragam pertanyaan seperti ini, mengindikasikan masih adanya penyidik yang belum menguasai strategi bertanya yang baik dan efektif.

4. Ditemukannya ragam pertanyaan produktif yang lebih banyak dibandingkan pertanyaan tak produktif berdampak terhadap tingginya nilai bukti BAP sebagai alat bukti surat yang disampaikan di persidangan. Kekuatan nilai bukti BAP sebagai alat bukti surat di persidangan mengandung makna bahwa BAP ini dapat mengantisipasi adanya gugatan pencabutan keterangan dari para tersangka, dan mampu menjelaskan secara rinci kejadian pidana secara akurat. Dengan demikian, BAP yang bernilai bukti tinggi dapat dijadikan salah satu acuan bagi hakim dalam memutuskan hukuman pidana dengan seadil-adilnya. 


\section{CATATAN}

* Penulis berterima kasih kepada mitra bestari yang telah memberikan saran-saran untuk perbaikan artikel ini. Artikel ini merupakan salah satu bagian laporan analisis dalam Disertasi penulis (Andika Dutha Bachari) yang berjudul "Wawancara Investigatif dan Daya Bukti Berita Acara Pemeriksaan dalam Sistem Peradilan Pidana di Indonesia" yang dipromotori oleh Dadang Sudana dan Wawan Gunawan. Secara khusus, kami mengucapkan terima kasih kepada E. Aminudin Aziz yang telah bersedia menelaah artikel ini secara cermat. Masukan-masukan yang diberikan untuk perbaikan artikel ini sangatlah berharga.

\section{DAFTAR PUSTAKA}

Analiyansyah, A., dan Rahmatillah, S. (2015). Perlindungan terhadap anak yang berhadapan dengan hukum (Studi terhadap undang-undang peradilan anak Indonesia dan peradilan adat Aceh). Gender Equality: Internasional Journal of Child and Gender Studies, 1(1), $51-68$.

Austin, J. L. (1962). How to do things with words. Cambridge: Harvard University Press.

Aziz, E. A., dkk. (2013). Ancangan baru aplikasi linguistik untuk sistem peradilan di Indonesia: Sebuah contoh penyiapan berita acara pemeriksaan (BAP) oleh polisi versus pengakuan terperiksa. Artikel dalam Prosiding Kongres Internasional Masyarakat Linguistik Indonesia (KIMLI) 2013, Bandar Lampung.

Baldwin, J. (1993). Police interview techniques: Establishing truth or proof? The British Journal of Criminology, 325-352.

Baldwin, J. dan McConville, M. (1980). Confessions in the crown court . Research Study No. 5, Royal Commission on Criminal Procedure. London: HMSO.

Clarke, C. dan Milne, R. (2001). National evaluation of the PEACE investigative interviewing course. Police Research Award Scheme Report No: PRAS/149. London, United Kingdom.

Corbin, J. M., dan Strauss, A. (1990). Grounded theory research: Procedures, canons, and evaluative criteria. Qualitative Sociology, 13(1), 3-21.

Detik.com.(April, 2014). Disiksa Babinsa TNI, 5 anak dipaksa mengaku memperkosa bocah usia 9 tahun. Diperoleh 20 Februari 2017, dari https://news.detik.com/berita/2560645/disiksababinsa-tni-5-anak-dipaksa-mengaku-memperkosa-bocah-usia-9-tahun?9911012=.

Fisher, K. J. (2013). Moral and legal responsibility of child soldiers. In Transitional Justice for Child Soldiers (pp. 61-84). Palgrave Macmillan UK.

George, R. dan Clifford, B. (1992). Making the most of witnesses policing. 8(3), 185-198.

Glaser, B. G. (1992). Basics of grounded theory analysis: Emergence vs forcing. Sociology Press.

Gregory, M. (2011). A comparison of US police interviewers' notes with their subsequent reports. Journal of Investigative Psychology and Offender Profiling. 8(2), 203-215.

Griffiths, A., dan Milne, R. (2006). Will it all end in tiers? Police interviews with suspects in Britain. Investigative interviewing, 167-189. 
Harahap, M. Y. (2005). Pembahasan permasalahan dan penerapan KUHAP: Pemeriksaan sidang pengadilan, banding, kasasi, dan peninjauan kembali. Edisi kedua. Jakarta: Sinar Grafika.

Hassler, W. G. (1930). Reptile study. Boy Scouts of America.

Heydon, G. (2012). Helping the police with their enquiries: Enhancing the investigative interview with linguistic research. The Police Journal, 85(2), 101-122.

Holmberg, U., dan Christianson, S. Å. (2002). Murderers' and sexual offenders' experiences of police interviews and their inclination to admit or deny crimes. Behavioral sciences \& the law, 20(1-2), 31-45.

Inbau, F.E., Reid, J.E. dan Buckley, J.P. (1986). Criminal interrogation and confessions. Williams \& Watkins: Baltimore.

Katzin, L. I., dan Gebert, E. (1954). Solvent effects in the Iodide-Iodine-Triiodide complex equilibrium 1. Journal of the American Chemical Society, 76(8), 2049-2054.

Komisi Perlindungan Anak Indonesia. (Januari, 2017). Rincian tabel data kasus pengaduan anak berdasarkan klaster perlindungan anak. Diperoleh 20 Februari 2017, dari http://bankdata.kpai.go.id/tabulasi-data/data-kasus-per-tahun/rincian-data-kasusberdasarkan-klaster-perlindungan-anak-2011-2016.

Kompas. (Januari, 2012). Kejamnya keadilan "Sandal Jepit". Diperoleh 20 Februari 2017, dari http://nasional.kompas.com/read/2012/01/06/09445281/Kejamnya.Keadilan. Sandal.Jepit.

Kompas. (Juli, 2009). PN Tangerang sidangkan 10 anak yang main judi. Diperoleh 20 Februari 2017, dari http://megapolitan.kompas.com/read/2009/07/13/15172914/pn.tangerang. sidangkan.10.anak.yang.main.judi.

Kondori, A. (2015). Study the effect of family economic security on social harms. International Research Journal of Applied and Basic Sciences, 9(11), 2069-2080.

Kurniawan, A. C. (2014). Pendekatan restorative justice dalam penyelesaian tindak pidana anak oleh Polres Tegal. Disertasi tidak diterbitkan. Program Studi Ilmu Hukum FH-UKSW.

Maskur, M. A. (2012). Perlindungan hukum terhadap anak nakal (Juvenile delinquency) dalam proses acara pidana Indonesia. Pandecta: Research Law Journal, 7(2).171-181.

McElhinny, B. (2003). Fearful, forceful agents of the law: Ideologies about language and gender in police officers' narratives about the use of physical force. Pragmatics, 13(2), 253284.

McGurk, B.J., Carr, M.J. dan McGurk, D. (1993). Investigative interviewing courses for police officers: an evaluation. Police Research Series: Paper No.4. Home Office: London.

Milne, R. dan Bull, R (1999). Investigative Interviewing: Psychology and Practice. John Wiley and Sons Ltd: Chichester.

Milne, R., dan Bull, R. (2006). Interviewing victims of crime, including children and people with intellectual disabilities. Practical psychology for forensic investigations and prosecutions, 7-24.

Novira, M., dan Marlina, M. (2013). Kebijakan penanggulangan kejahatan terhadap anak pelaku tindak pidana dari perspektif undang-undang Republik Indonesia Nomor 11 Tahun 2012 tentang sistem peradilan pidana anak. Jurnal Mahupiki, 1 (1).1-29. 
Nugrahaeni, N. A. (2009). Sistem pemidanaan edukatif terhadap anak sebagai pelaku tindak pidana. Tesis tidak dipublikasikan. Fakultas Hukum, Universitas Dipenogoro, Semarang.

Oxburgh, G. E., Myklebust, T., dan Grant, T. (2010). The question of question types in police interviews. Int. J. Speech Lang. Law, 17(1), 45-66.

Pompe, S. (2005). The Indonesian supreme court: A study of institutional collapse (No. 39). SEAP Publications.

Prasetyo, H. (2015). Sejarah perkembangan ketenagakerjaan di Indoneisa. Jakarta: Kompas.

Robert, H. (2001). The juvenile offender: Theory, research, and applications. NewYork: Springer.

Searle, J. R. (1969). Speech Acts: An essay in the philosophy of language.Oxford: Cambridge University Press.

Shaw, G. (1996). The new PEACE. Police Review. 5 January, pp26-27.

Shawyer, A. (2009). Investigative interviewing: Interviewing counter fraud and deception. Unpublished Ph.D. thesis, University of Portsmouth.

Shawyer, A. dan Milne, R. (2009). Investigative interviewing: Investigation, counter-fraud and behavior. Paper presented at the 2nd International Investigative Interviewing Research Group Conference, University of Teesside.

Shepherd, S. A., dan Brown, L. D. (1993). What is an abalone stock: Implications for the role of refugia in conservation. Canadian Journal of Fisheries and Aquatic Sciences, 50(9), 2001-2009.

Strauss, A., \& Corbin, J. (1967). Discovery of grounded theory.

Walsh, D.dan Bull, R. (2011). Benefit fraud investigative interviewing: A self-report study of investigation professionals' beliefs concerning practice. Journal of Investigative Psychology and Offender Profiling, 8, 131-148.

Wakefield, S. (2014). Police use of interpreters: Understanding police perceptions, recognising current practice and informing best practice. Unpublished thesis of Doctor of Philosophy in Policing and Security. School of Applied Psychology Griffith University, Queensland.

Walsh, D., dan Oxburgh, G. E. (2008). Investigative interviewing of suspects: Historical and contemporary developments in research. Forensic Update.

Walsh, D.dan Milne, R. (2007). Giving PEACE a chance. Public Administration. 85 (3), $525-$ 540.

Williamson, T. M. (1993). From interrogation to investigative interviewing: Strategic trends in police questioning. Journal of Community \& Applied Social Psychology, 3(2), 89-99.

\section{ATURAN PERUNDANG-UNDANGAN}

Deklarasi Hak-hak Anak pada tahun 1959.

Keputusan Presiden Nomor 39 Tahun 1990 tentang Ratifikasi Konvensi Hak Anak (yang disahkan Majelis Umum PBB pada 20 November 1989). 
Peraturan Kepala Kepolisian Negara Republik IndonesiaNo. 8 tahun 2009 tentang Implementasi Prinsip dan Standar Hak Asasi Manusia dalam Penyelenggaraan Tugas Pokok Polri.

Peraturan Kepala Kepolisian Negara Republik Indonesia Nomor 14 Tahun 2012 tentang Manajemen Penyidikan Tindak Pidana.

Stb. 1925 Nomor 647 tentang Pembatasan Kerja Anak dan Wanita.

Stb. 1926 Nomor 87 tentang Pembatasan Anak dan Orang Muda yang Bekerja di atas Kapal.

Surat Keputusan Kapolri Nomor 1205/IX/2000 tentang Petunjuk Pelaksanaan dan Petunjuk Teknis Penyidikan Pidana

Undang-Undang No. 11 Tahun 2012 tentang Sistem Peradilan Pidana Anak.

Undang-Undang No. 8 Tahun 1981 tentang Hukum Acara Pidana

Undang-Undang No.4 Tahun 1979 tentang Kesejahteraan Anak.

Undang-Undang Nomor 1 tahun 1946 tentang Peraturan Hukum Pidana

Undang-Undang Nomor 20 Tahun 1999 tentang Peratifikasian Konvensi International Labor Organization tentang Usia Minimum Anak yang Diperbolehkan Bekerja.

Undang-Undang Nomor 23 Tahun 2002 tentang Perlindungan Anak.

Undang-Undang Nomor 39 Tahun 1999 tentang Hak Asasi Manusia. 